\title{
THE EFFECT OF CUSHING'S SYNDROME UPON SERUM ALBUMIN METABOLISM *
}

\author{
By KENNETH STERLING \\ (From the Department of Internal Medicine, New York State Psychiatric Institute, and the \\ Department of Psychiatry, Columbia University College of Physicians and Surgeons, \\ New York, N. Y.)
}

(Submitted for publication June 10, 1960; accepted August 17, 1960)

The present investigation of albumin metabolism in Cushing's syndrome employing the $\mathrm{I}^{131}$ labeled albumin turnover method (1) was undertaken in view of clinical and experimental evidence of significant effects of steroid hormones upon protein metabolism. Previous reports have described acute effects of large doses of glucocorticoids in human subjects $(2-4)$. The effects of chronic hyperadrenalism were examined in the present work.

\section{MATERIAL AND METHODS}

\section{Clinical material}

The following four categories of subjects were studied: 1) normal volunteers, 2) physically healthy hospitalized schizophrenic patients, 3) cases of Cushing's syndrome due to adrenal cortical hyperplasia ; and 4) a patient with Cushing's syndrome due to exogenous steroids.

1) Normal volunteers. Thirteen subjects, 10 male, 3 female with ages ranging from 19 to 40 years.

2) Physically healthy hospitalized schizophrenic patients. Ten subjects, 5 male, 5 female with ages ranging from 17 to 39 years.

3) Cushing's syndrome. Albumin turnover studies were carried out on 4 women during the active stage of clinically typical Cushing's syndrome attributed to bilateral adrenal hyperplasia. Three of the 4 were studied again after therapy and remission. The diagnoses were supported by elevated urinary ketogenic steroids or corticoids (Porter-Silber chromogens). In M.W., administration of prednisone was followed by suppression of urinary 17 -ketosteroid levels. In the other 3 subjects, intravenous ACTH was followed by an exaggerated rise in plasma corticoids, considered indicative of hyperplasia rather than tumor (5). None of the women exhibited appreciable virilization. All had amenorrhea; the 3 of pre-menopausal age resumed menstruation after therapy.

M.W., aged 36, had severe Cushing's syndrome with osteoporosis and collapsed lumbar vertebrae, hypertension, intermittent hypokalemic alkalosis, and increased

* Supported by grants from the National Institutes of Health, the American Cancer Society, and the National Foundation for Neuromuscular Diseases, and by a research contract with the U. S. Atomic Energy Commission. requirement of insulin for diabetes mellitus which apparently antedated the onset of hyperadrenalism. After complete removal of enlarged adrenal glands, the patient resumed menstruation for the first time in several years. She was given relatively large steroid doses in an effort to minimize orthostatic hypotension and episodes of Addisonian crisis associated with intercurrent infections. When restudied with $\mathrm{I}^{131}$-albumin 15 months after total adrenalectomy, the patient was receiving $30 \mathrm{mg}$ cortisol, $0.5 \mathrm{mg}$ 9- $\alpha$-fluorocortisol, and $1 \mathrm{~g}$ tolbutamide daily.

C.H., aged 50, had Cushing's syndrome of moderate severity with hypertension but no diabetes or osteoporosis. She had facial rounding, cervico-dorsal and supraclavicular fat pads, and thin skin with a few pink striae. She had been emotionally disturbed and required care in a mental hospital during both initial and follow-up studies. She was restudied with $\mathrm{I}^{131}$-albumin 10 months after total adrenalectomy, while receiving $20 \mathrm{mg}$ cortisone daily.

R.H., aged 32, had Cushing's syndrome of minimal severity with hypertension but no impaired glucose tolerance or osteoporosis. She had some facial rounding, hirsutism, amenorrhea, easy bruisability, and increased pigmentation. Following irradiation of the pituitary $(4,080 \mathrm{r})$, the elevated urinary 17 -ketosteroids and ketogenic steroids fell to the normal range. Menses reappeared for the first time in 7 months. The patient's general appearance was improved at the time of the second $\mathrm{I}^{131}$-albumin study 10 months after radiotherapy.

A.G., aged 38, had mild Cushing's syndrome with amenorrhea, facial rounding, acne, hirsutism, supraclavicular fat pads, and ecchymoses. After removal of one hyperplastic adrenal gland, she underwent what was considered coincidental partial remission with return of menses. During the next 6 years there were intermittent manifestations of moderate activity of the disease. This was followed by a severe re-exacerbation with hypertension, glycosuria, and osteoporosis with a collapsed lumbar vertebra. During the $\mathrm{I}^{131}$-albumin turnover study, the patient received radiotherapy to the pituitary without diminution of the elevated urinary ketogenic steroid values. Four months after the pituitary irradiation (approximately $4,000 \mathrm{r}$ ), there was general clinical improvement and recurrence of menses. The elevated urinary ketogenic steroids fell to normal. A follow-up $\mathrm{I}^{131}$-albumin study was not carried out.

4) Cushing's syndrome due to exogenous steroids. E.B., a 43 year old woman, had dermatomyositis verified 
by biopsy. The initial $I^{131}$-albumin study was done during the third month of cortisone therapy $(200 \mathrm{mg}$ per day). A later albumin study was carried out during the second month of a higher dosage schedule $(300 \mathrm{mg}$ per day). During both studies, the patient presented the typical appearance of Cushing's syndrome with marked facial rounding and "buffalo" obesity.

\section{Methods}

Total serum protein concentrations were determined in duplicate by the biuret method, employing two or more known standards prepared by dry weight or checked by Kjeldahl analysis. The albumin values were obtained by paper electrophoresis in duplicate with the standard Spinco apparatus and Analytrol. The albumin concentration was determined at least twice in each subject, at the beginning and end of the turnover study, with additional intermediate determinations in many instances. The albumin values obtained in each subject agreed within $0.4 \mathrm{~g}$ per $100 \mathrm{ml}$ or less.

The radioiodinated serum albumin shipments were obtained from E. R. Squibb and Sons or from Abbott Laboratories. Immediately upon receipt of each lot from Abbott Laboratories, carrier albumin (25 to $50 \mathrm{mg}$ Red Cross albumin) was added to the vial to minimize radiation damage to the labeled protein (6). The Squibb solutions were stated to contain about 10 to $15 \mathrm{mg}$ protein per $\mathrm{ml}$, which was considered, satisfactory from the standpoint of self-irradiation.

Each hyperadrenal patient was studied simultaneously with two or more control subjects to avoid any possible discrepancies that could arise from different behavior in vivo of individual shipments of radioiodinated albumin. No variation between different lots was observed. Urine collections during the first day after injection revealed that amounts not exceeding 10 per cent of the injected radioactivity had been excreted, a finding compatible with absence of appreciable amounts of abnormal rapidly degraded components $(1,7)$.

After 1 day or more of iodine prefeeding (Lugol's solution, 15 drops daily), the subjects received 50 to $100 \mu \mathrm{c}$ of $\mathrm{I}^{131}$-labeled albumin by intravenous injection. Heparinized venous plasma samples were obtained 10 minutes after injection, and daily or three times weekly for three or more weeks.

In several of the experimental and control subjects, 24-hour urine collections were obtained during most or all of the study period. The completeness of the collections was verified by creatinine determinations.

The plasma samples of each subject were counted with appropriate standards in a well-type scintillation counter, usually at the conclusion of the study, thus obviating the need for physical decay corrections. Other samples, including urines, were corrected when necessary for physical decay.

The data on plasma radioactivity were treated as originally described (1). Disappearance curves were obtained from semilogarithmic plots of the plasma radioactivity against time (Figures 2 and 3 ). The rapid ini- tial fall of the first few days, attributed to distribution of the tracer throughout the "total exchangeable albumin pool," was followed by a gradual linear decline, the exponential decay due to metabolic degradation. Lines were drawn by inspection, or by the method of least squares when the points showed appreciable scatter. The half-time $\left(\mathrm{T}_{\frac{1}{2}}\right)$ of the slow component was obtained by graphic analysis. From the $T_{\frac{1}{2}}$ the equation, $0.693 / T_{\frac{1}{2}}=$ $k$, gave the fractional turnover rate, $k$, expressed as per cent of the albumin pool replaced per day. The total exchangeable albumin pool in grams was obtained by the isotope dilution formula, employing the quotient:

$$
\frac{\text { total radioactivity injected }}{\text { adioactivity per gram of albumin }} \text {. }
$$

The denominator was obtained from the zero time extrapolation of the slow component which represented plasma radioactivity if distribution had occurred instantaneously upon injection. The product of the pool and turnover rate yielded the degradation rate in grams per day. The rate of synthesis should be the same as the degradation rate under steady state conditions, which were assumed to exist in the absence of significant clinical alterations. The observed constancy of the serum albumin concentration was compatible with this assumption. The data for the albumin pools and degradation rates were adjusted to $1.73 \mathrm{~m}^{2}$ surface area. The intravascular albumin (circulating plasma albumin) in grams was calculated from the 10 minute value for radioactivity per gram of albumin used as the denominator in the isotope dilution formula.

The data on urinary radioactivity were treated by two types of computation described by Rothschild, Schreiber, Oratz and McGee (2) and by Berson, Bauman and Rothschild (7-9). One value for the albumin degradation rate was obtained from the quotient:

per cent renal excretion per day

per cent injected radioactivity retained in the body

which was multiplied by the total exchangeable albumin pool $(7,8)$. A second value was the product of the "metabolic clearance" of $\mathrm{I}^{131}$-albumin and the mean serum albumin concentration $(2,9)$. The results of both methods based upon urinary data proved to be in reasonable agreement with the values obtained from plasma disappearance curves, which were used in Table I and in Figures 1, 2 and 3. Extensive discussions of the validity and limitations of $\mathrm{I}^{131}$-albumin turnover studies have appeared previously $(6,7,10-13)$.

\section{RESULTS AND INTERPRETATIONS}

The normal control and schizophrenic groups had biological half-times of albumin turnover (mean \pm standard deviation) of $13.4 \pm 1.3$, and $13.5 \pm 1.3$ days, respectively (Figure 1 and Table I). No significant variation related to age or sex was observed. 
Albumin turnover data in Cushing's syndrome and control groups

\begin{tabular}{|c|c|c|c|c|c|c|c|c|c|c|c|c|c|}
\hline \multirow[b]{3}{*}{ Condition } & \multirow[b]{3}{*}{ Subject } & \multirow[b]{3}{*}{ Sex } & \multirow[b]{3}{*}{ Age } & \multirow[b]{3}{*}{ Wt } & \multirow[b]{3}{*}{$\begin{array}{l}\text { Surface } \\
\text { area }\end{array}$} & \multirow[b]{3}{*}{ Status } & \multirow[b]{3}{*}{$\begin{array}{l}\text { Serum } \\
\text { albumin }\end{array}$} & \multicolumn{6}{|c|}{ Kinetic and isotope dilution data } \\
\hline & & & & & & & & \multicolumn{2}{|c|}{$\begin{array}{l}\text { Kinetics of } \\
\text { disappearance }\end{array}$} & \multirow{2}{*}{\multicolumn{2}{|c|}{$\begin{array}{l}\text { Total ex- } \\
\text { changeable } \\
\text { albumin } \\
\text { pool }\end{array}$}} & \multirow{2}{*}{\multicolumn{2}{|c|}{$\begin{array}{c}\text { Degradation } \\
\text { rate }\end{array}$}} \\
\hline & & & & & & & & $T_{\frac{1}{2}}$ & $\begin{array}{l}\text { Turn- } \\
\text { over } \\
\text { rate }\end{array}$ & & & & \\
\hline & & & yrs & $k g$ & $m^{2}$ & & $g \%$ & days & $\% / d a y$ & $g$ & $\begin{array}{l}g / 1.73 \\
m^{2}\end{array}$ & $g / d a y$ & $\begin{array}{l}\mathrm{g} / \mathrm{day} / \\
1.73 \mathrm{~m}^{2}\end{array}$ \\
\hline \multirow[t]{2}{*}{$\begin{array}{l}\text { Cushing's } \\
\text { syndrome }\end{array}$} & M.W. & $\mathrm{F}$ & 36 & 66.0 & 1.65 & $\begin{array}{l}\text { Disease active; } \\
\text { osteoporosis }\end{array}$ & 3.8 & 7.7 & 9.0 & 170 & 178 & 15.3 & 16.0 \\
\hline & & & 37 & 61.9 & 1.60 & $\begin{array}{l}15 \text { mos. after } \\
\text { adrenalectomy }\end{array}$ & 2.7 & 10.8 & 6.4 & 208 & 225 & 13.3 & 14.5 \\
\hline \multirow{2}{*}{$\begin{array}{l}\text { Cushing's } \\
\text { syndrome }\end{array}$} & C.H. & $\mathrm{F}$ & 50 & 65.0 & 1.62 & Disease active & 4.7 & 9.7 & 7.2 & 250 & 267 & 17.9 & 19.1 \\
\hline & & & 51 & 46.8 & 1.41 & $\begin{array}{l}10 \text { mos. after } \\
\text { adrenalectomy }\end{array}$ & 4.3 & 14.3 & 4.8 & 266 & 326 & 12.9 & 15.8 \\
\hline \multirow{2}{*}{$\begin{array}{l}\text { Cushing's } \\
\text { syndrome }\end{array}$} & R.H. & $\mathrm{F}$ & 32 & 63.6 & 1.66 & Disease active; & 4.6 & 11.4 & 6.1 & 293 & 305 & 17.9 & 18.7 \\
\hline & & & 33 & 63.2 & 1.66 & $\begin{array}{l}10 \text { mos. after } \\
\text { pit. irradiation }\end{array}$ & 4.4 & 15.4 & 4.5 & 394 & 411 & 17.7 & 18.5 \\
\hline \multirow[t]{2}{*}{$\begin{array}{l}\text { Cushing's } \\
\text { syndrome }\end{array}$} & A.G. & $\mathrm{F}$ & 38 & 56.6 & 1.58 & $\begin{array}{l}\text { Disease active; } \\
\text { osteoporosis }\end{array}$ & 3.6 & 8.5 & 8.2 & 179 & 196 & 14.6 & 16.0 \\
\hline & & & & & Active ( & ushing's syndrome: & $\begin{array}{l}\text { Mean } \\
\text { SI } \\
\text { SHM* }\end{array}$ & $\begin{array}{l}9.3 \\
1.6 \\
0.8\end{array}$ & $\begin{array}{l}7.6 \\
1.2 \\
0.6\end{array}$ & $\begin{array}{r}223 \\
59 \\
29\end{array}$ & $\begin{array}{r}237 \\
60 \\
30\end{array}$ & $\begin{array}{r}16.4 \\
1.7 \\
0.9\end{array}$ & $\begin{array}{r}17.5 \\
1.7 \\
0.8\end{array}$ \\
\hline \multirow[t]{2}{*}{$\begin{array}{l}\text { Cortisone } \\
\text { therapy }\end{array}$} & E.B. & $\mathrm{F}$ & 43 & 75.0 & 1.78 & $\begin{array}{l}\text { 3rd mo., } 200 \mathrm{mg} \\
\text { cortisone daily; }\end{array}$ & 4.2 & 10.1 & 6.9 & 261 & 254 & 18.0 & 17.5 \\
\hline & & & 43 & 75.0 & 1.78 & $\begin{array}{l}\text { 2nd mo., } 300 \mathrm{mg} \\
\text { cortisone daily }\end{array}$ & 4.7 & 8.6 & 8.1 & 261 & 254 & 21.0 & 20.4 \\
\hline Normal & & & & & & 13 Subjects: & $\begin{array}{l}\text { Mean } \\
\text { SD } \\
\text { SEM }\end{array}$ & $\begin{array}{r}13.4 \\
1.3 \\
0.4\end{array}$ & $\begin{array}{l}5.2 \\
0.5 \\
0.1\end{array}$ & $\begin{array}{r}314 \\
48 \\
13\end{array}$ & $\begin{array}{r}300 \\
37 \\
10\end{array}$ & $\begin{array}{r}16.3 \\
2.9 \\
0.8\end{array}$ & $\begin{array}{r}15.6 \\
2.2 \\
0.6\end{array}$ \\
\hline Schizophrenia & & & & & & 10 Subjects: & $\begin{array}{l}\text { Mean } \\
\text { SD } \\
\text { SEM }\end{array}$ & $\begin{array}{r}13.5 \\
1.3 \\
0.4\end{array}$ & $\begin{array}{l}5.2 \\
0.5 \\
0.2\end{array}$ & $\begin{array}{r}323 \\
64 \\
20\end{array}$ & $\begin{array}{r}318 \\
37 \\
12\end{array}$ & $\begin{array}{r}16.6 \\
3.0 \\
1.0\end{array}$ & $\begin{array}{r}16.4 \\
1.8 \\
0.6\end{array}$ \\
\hline
\end{tabular}

* Standard error of the mean.

The subjects with active Cushing's syndrome had significantly shorter half-times with a mean value of $9.3 \pm 1.6$ days $(p<0.01)$. This acceleration of albumin turnover was reversed by treatment of the disease. As seen in Figures 1, 2 and 3 and in Table I, the $T_{\frac{1}{2}}$ became appreciably longer, returning to or toward the normal range in the three subjects restudied during remission following therapy. Repeated studies in control subjects at intervals as long as 1 year have revealed no detectable change (14).

The mean value for the total exchangeable albumin pool was significantly reduced in the cases of Cushing's syndrome as compared with the normal $(p<0.05)$ and schizophrenic groups $(\mathrm{p}<$ $0.01)$. The albumin pools were smallest in M.W. and A.G., the two subjects with the shortest halftimes and with the most severe clinical manifestations, which included advanced osteoporosis. Nevertheless, there was no appreciable hypoalbuminemia.

Subject E.B., who was first studied while re- ceiving $200 \mathrm{mg}$, and again while receiving $300 \mathrm{mg}$ cortisone daily for dermatomyositis, also showed accelerated albumin turnover, more pronounced on the higher dose (Figure 1 and Table I). It should be mentioned that dermatomyositis per se was not found to be associated with abnormal albumin metabolism (14).

The total exchangeable albumin pool did not change in E.B. on the two different doses of cortisone. In contrast, each of the cases of Cushing's syndrome had a higher value for the albumin pool when restudied after therapy. With the increased albumin pool, M.W. exhibited an unchanged intravascular fraction of the pool (34 per cent, first study; 33 per cent, second study). The serum allumin concentration was diminished in association with expanded plasma volume. The precise cause of this hypervolemic hypoalbuminemia, and the possible contribution of excess salt and water retention with high steroid dosage were not clear. The other cases, C.H. and R.H., showed slight diminutions of the serum albumin concentration, 
opposite in direction to the increased values for the albumin pools.

No consistent variations in intravascular-extravascular distribution were observed. The mean values \pm standard deviations for the intravascular per cent of the total exchangeable albumin pool were: normal control group, $40.2 \pm 4.2$ per cent; schizophrenic group, $41.2 \pm 7.2$ per cent; and active Cushing's syndrome, $38.5 \pm 5.4$ per cent.

It was not unexpected that the degradation rates in Cushing's syndrome, being the products of diminished pools and increased turnover rates, revealed no marked deviations from the normal range. The values for albumin degraded and synthesized daily revealed some diminution after therapy in M.W. and C.H., but no appreciable change in R.H. Subject E.B. showed an increased degradation rate on the larger as compared with the smaller dose of cortisone.
DISCUSSION

On theoretical grounds it has been shown (12) that the methodology employed probably results in an overestimation of the total exchangeable albumin pool and that, in general, this overestimation becomes more serious with shorter biological half-times $(12,13)$. In the present study, the lower values for albumin pool in active Cushing's syndrome cannot be attributed to computational error, since the associated short half-times would tend to exaggerate the overestimation of total exchangeable albumin.

The findings illustrated accelerated albumin turnover associated with the excess glucocorticoids of spontaneous or exogenously induced Cushing's syndrome. This abnormality was reversed by definitive therapy and was accentuated by increased steroid dosage. The extent of deviation from normal appeared to be related to the severity of the clinical manifestations.

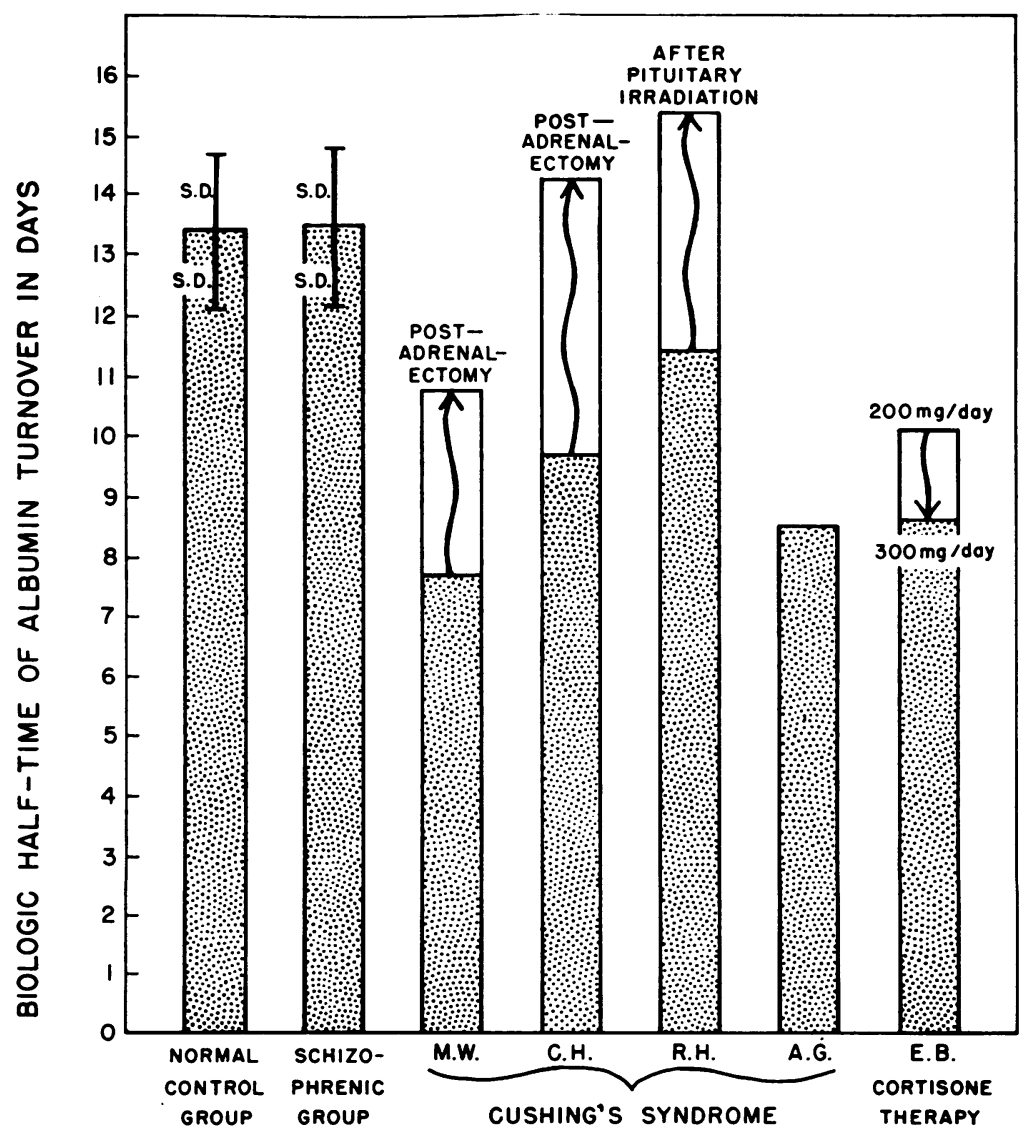

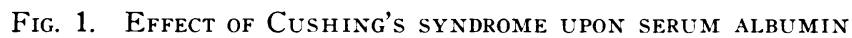
TUR NOVER. 


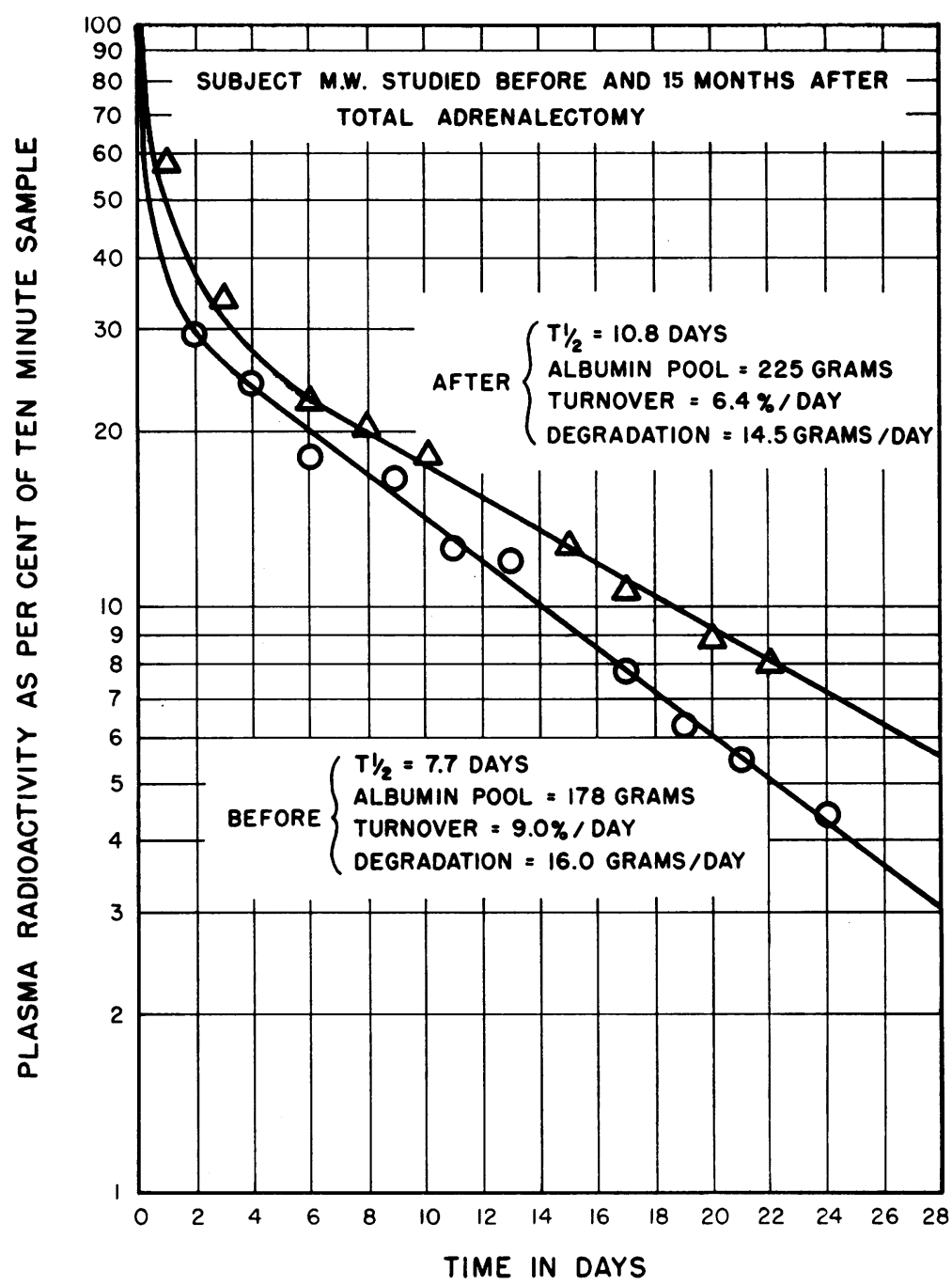

Fig. 2. I I31-Labeled albumin disappearance CuRve in Cushing's SynDROMe in Subject M.W. (SEmilogarithmic plot). The albumin pools and degradation rates are adjusted to $1.73 \mathrm{~m}^{2}$ surface area.

Human subjects started on large doses of glucocorticoids have manifested acutely increased albumin degradation, according to the reports of Rothschild and co-workers (2), Grossman, Yalow and Weston (3), and Blythe and associates (4).

Accelerated albumin turnover is by no means confined to Cushing's syndrome. It is seen in thyrotoxicosis $(11,14)$ as well as in the hypoproteinemias associated with proteinuria $(8,13,14)$ and with gastrointestinal protein-wasting syndromes (15-18). It is not, however, regularly associated with either malnutrition $(14,19)$ or debilitating illness. Subjects with marked wasting, including patients with advanced carcinoma, myotonic muscular dystrophy, and miscellaneous muscle diseases did not have accelerated albumin turnover, although some subjects had marked hypoalbuminemia and diminution of the total exchangeable albumin pool (14). This finding would tend to exclude the possibility that the accelerated turnover in Cushing's syndrome might be attributable to nonspecific effects of severe illness. The close similarity of the findings in the normal control and schizophrenic groups signifies the constancy of albumin metabolism despite emotional illness and wide variations in behavior.

The mechanism of the accelerated albumin turnover in Cushing's syndrome cannot be stated ex- 
plicitly at present. Certain inferences are warranted, however. In the absence of significant clinical alterations and with constancy of the serum albumin concentration, the subjects were considered to be in a "steady state" during the several weeks of each study. Therefore, the rate of synthesis was presumed to be equal to the rate of degradation. After therapy and remission, the computed degradation rate fell in two of the three cases; the albumin pool rose in each. Since the total exchangeable albumin values were not markedly diminished in active Cushing's syndrome (Table I), it may be inferred that accelerated albumin catabolism was at least partly compensated for by increased synthesis of albumin.
Conceivably, small discrepancies between synthesis and degradation persisting over long periods (months or years) may have led to the observed diminution in albumin pool. However, since Cushing's syndrome had been present for some time, and since the follow-up studies were done 10 to 15 months after therapy, no definite statement can be made concerning the precise sequence of the changes. As noted previously, the smallest albumin pools were found in the subjects with the shortest half-times, M.W. and A. G., with the most severe clinical manifestations, which included advanced osteoporosis.

An instance of compensatory increase in albumin synthesis is seen in Subject E.B. On the

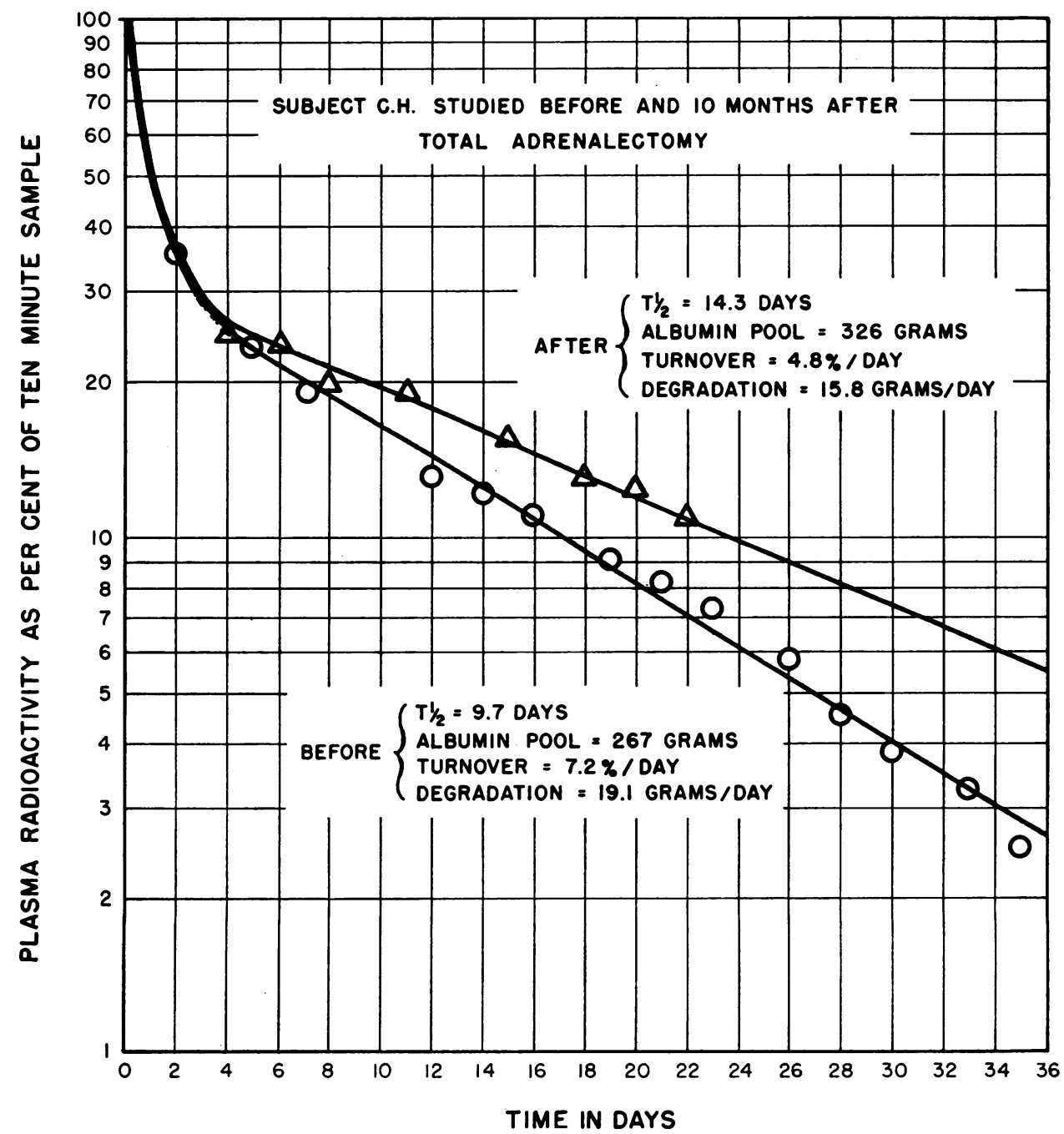

Fig. 3. I I31-labeled albumin disappearance curve in Cushing's syndrome in Subject C.H. (SEmIlogarithmic PLOT). The albumin pools and degradation rates are adjusted to 1.73 $\mathrm{m}^{2}$ surface area. 
higher steroid dose there was an accelerated turnover with increased rate of degradation and presumably of synthesis, but the value for total exchangeable albumin remained unchanged.

Further evidence bearing on this point is available in the report by Rothschild and co-workers (2) which describes the acute effects of 13 to 19 days of cortisol or prednisone administration. By injection of a second $\mathrm{I}^{131}$-albumin tracer during the period of steroid medication, it was possible to calculate a second total exchangeable albumin pool. The diminution in albumin pool associated with hormone treatment was definitely less than that expected from the increased degradation rate. Thus, in four male subjects, the authors reported a mean figure of $59 \mathrm{~g}$ as the increase in albumin degraded during steroid administration. Since the mean diminution in albumin pool was only 31 $\mathrm{g}$, the difference, $28 \mathrm{~g}$, was attributed to increased albumin synthesis. Even allowing for errors implicit in the methodology, it would appear likely from these data and from the present report, that glucocorticoids increase albumin synthesis as well as degradation under both short-term and longterm conditions.

The promotion of increased gluconeogenesis by adrenal cortical hormones has been the subject of much work since the animal experiments of Long, Katzin, and Fry (20) and the clinical observations of Albright (21). The detailed study by Hoberman (22) employed $\mathrm{N}^{15}$-glycine in fasting rats treated with cortisone, as well as in rats with increased endogenous steroid production in response to cold stress. The findings indicated that excess glucocorticoids caused acceleration of the catabolism of body protein to amino acils, as well as the catabolism of amino acids to urea, but caused reduction of the synthesis of body protein from amino acids. The patients with Cushing's syndrome given $\mathrm{N}^{15}$-glycine by Parson, Crispell and Ebbert (23) revealed a markedly increased rate of $\mathrm{N}^{15}$ excretion in the urine, despite maintenance of nitrogen equilibrium as shown by balance study.

The evidence of the protein-wasting action of the adrenal cortical hormones refers to the overall effect upon the body, but does not require the assumption that the same processes occur in the different tissues. Direct evidence to the contrary is provided by animal experiments showing net protein anabolism in some tissues simultaneously with catabolism in others. Silber and Porter observed wastage of nitrogen from the carcasses of cortisone-treated rats, with concurrent increase in the total protein of the liver and other viscera as well as increased plasma albumin concentration (24). Clark carried out analyses of the carcasses and livers of control and cortisone-treated rats which were given $\mathrm{N}^{15}$-glycine (25). The lower $\mathrm{N}^{15}$ content in carcass protein of the cortisonetreated animals indicated diminished protein synthesis. In contrast, the liver protein nitrogen and $\mathrm{N}^{15}$ were increased in the treated rats, as were the serum protein concentration and its $\mathrm{N}^{15}$ content. The increased urinary nitrogen and $\mathrm{N}^{15}$ excretion observed was attributed to the reduced protein synthesis in the carcass which outweighed the increased hepatic activity in serum and liver protein synthesis. The increased metabolism of the liver was viewed as probably a "compensatory" reaction. Such may also be the case in the present study in which increased hepatic albumin synthesis presumably tended to offset increased degradation.

This difference in the behavior of liver as compared with muscle and carcass protein is not entirely unexpected. Earlier work such as the $\mathrm{N}^{15}$ glycine studies of Shemin and Rittenberg (26), and Sprinson and Rittenberg (27) revealed the greater protein turnover of the liver as compared with the less metabolically active tissues of the carcass. It would appear, then, that hepatic synthetic mechanisms either have the ability to compensate, or perhaps are directly stimulated by experimental or clinical hyperadrenalism. In contrast, impaired ability to compensate for increased catabolism in less active tissues would produce the protein-wasting seen in the osteoporosis, muscle atrophy, thin skin, and diminished fibrous tissue repair of Cushing's syndrome.

In the present group of patients who showed no appreciable virilization, the abnormalities were ascribed to the demonstrated excess of 17-hydroxycorticosteroids, which were not subjected to further analysis, such as chromatographic separation. The findings in virilizing adrenal disorders and the effects of the adrenal androgen, dehydroisoandrosterone (28), remain to be explored. 


\section{SUM MARY}

1. $\mathrm{I}^{131}$-labeled albumin turnover studies were carried out in four patients with Cushing's syndrome due to adrenal cortical hyperplasia and in control subjects.

2. In active Cushing's syndrome there was a short biological half-time of the tracer, signifying accelerated turnover.

3. This abnormality was reversed after therapy and remission.

4. Cushing's syndrome due to the administration of cortisone also revealed accelerated albumin turnover, more pronounced with a larger dose.

5. The total exchangeable albumin pool was reduced in Cushing's syndrome, and was smallest in the two subjects with the shortest half-times and with the most severe clinical manifestations.

6. Excess glucocorticoids were considered to have produced accelerated albumin catabolism, partly compensated for by increased synthesis.

\section{ACKNOWLEDGMENTS}

The author wishes to express gratitude to the late Dr. Joseph W. Jailer and to Dr. Nicholas P. Christy for help in acquiring clinical material. Philip Rosen and Robert Danziger rendered valuable technical assistance.

\section{REFERENCES}

1. Sterling, K. The turnover rate of serum albumin in man as measured by $\mathrm{I}^{131}$-tagged albumin. $\mathrm{J}$. clin. Invest. 1951, 30, 1228.

2. Rothschild, M. A., Schreiber, S. S., Oratz, M., and McGee, H. L. The effects of adrenocortical hormones on albumin metabolism studied with albu$\min -\mathrm{I}^{131}$. J. clin. Invest. 1958, 37, 1229.

3. Grossman, J., Yalow, A. A., and Weston, R. E. Albumin degradation and synthesis as influenced by hydrocortisone, corticotropin and infection. Metabolism 1960, 9, 528.

4. Blythe, W. B., Iber, F. L., Werner, I., Rubini, M. E., Frick, P. G., and Meroney, W. H. The effect of hydrocortisone on simultaneously determined albumin turnover and nitrogen balance (abstract). Clin. Res. Proc. 1957, 5, 190.

5. Christy, N. P., Longson, D., Jailer, J. W. Studies in Cushing's syndrome. I. Observations on the response of plasma 17-hydroxycorticosteroid levels to corticotropin. Amer. J. Med. 1957, 23, 910.

6. Yalow, R. S., and Berson, S. A. Chemical and biological alterations induced by irradiation of $\mathrm{I}^{131}$ la- beled human serum albumin. J. clin. Invest. 1957, $36,44$.

7. Berson, S. A., Yalow, R. S., Schreiber, S. S., and Post, J. Tracer experiments with $\mathrm{I}^{131}$ labeled human serum albumin: Distribution and degradation studies. J. clin. Invest. 1953, 32, 746.

8. Bauman, A., Rothschild, M. A., Yalow, R. S., and Berson, S. A. Distribution and metabolism of $I^{131}$ labeled human serum albumin in congestive heart failure with and without proteinuria. J. clin. Invest. 1955, 34, 1359.

9. Rothschild, M. A., Bauman, A., Yalow, R. S., and Berson, S. A. The effect of large doses of desiccated thyroid on the distribution and metabolism of albumin $-\mathrm{I}^{131}$ in euthyroid subjects. J. clin. Invest. 1957, 36, 422.

10. Lewallen, C. G., Berman, M., and Rall, J. E. Studies of iodoalbumin metabolism. I. A mathematical approach to the kinetics. J. clin. Invest. 1959, 38, 66.

11. Lewallen, C. G., Rall, J. E., and Berman, M. Studies of iodoalbumin metabolism. II. The effects of thyroid hormone. J. clin. Invest. 1959, 38, 88.

12. Masouredis, S. P. The role of $\mathrm{I}^{131}$-labeled proteins in biology and medicine; concluding remarks. Ann. N. Y. Acad. Sci. 1957, 70, 150.

13. Gitlin, D., Janeway, C. A., and Farr, L. E. Studies on the metabolism of plasma proteins in the nephrotic syndrome. I. Albumin, $\gamma$-globulin and iron-binding globulin. J. clin. Invest. 1956, 35, 44.

14. Sterling, K. Unpublished observations.

15. Citrin, Y., Sterling, K., and Halsted, J. A. The mechanism of hypoproteinemia associated with giant hypertrophy of the gastric mucosa. New Engl. J. Med. 1957, 257, 906.

16. Schwartz, M., and Jarnum, S. Gastrointestinal protein loss in idiopathic (hypercatabolic) hypoproteinaemia. Lancet 1959, 1, 327.

17. Gordon, R. S., Jr., Bartter, F. C., and Waldmann, T. Idiopathic hypoalbuminemias: Clinical staff conference at the National Institutes of Health. Ann. intern. Med. 1959, 51, 553.

18. Holman, H., Nickel, W. F., Jr., and Sleisenger, M. H. Hypoproteinemia antedating intestinal lesions, and possibly due to excessive serum protein loss into the intestine. Amer. J. Med. 1959, 27, 963.

19. Gitlin, D., Cravioto, J., Frenk, S., Montano, E. L., Galvan, R. R., Gomez, F., and Janeway, C. A. Albumin metabolism in children with protein malnutrition. J. clin. Invest. 1958, 37, 682.

20. Long, C. N. H., Katzin, B., and Fry, E. G. Adrenal cortex and carbohydrate metabolism. Endocrinology 1940, 26, 309.

21. Albright, F. Cushing's syndrome: Its pathologic physiology, its relationship to the adreno-genital syndrome, and its connection with the problem of the reaction of the body to injurious agents ("Alarm 
Reaction" of Selye). Harvey Lect. 1942-1943, 38, 123.

22. Hoberman, H. D. Endocrine regulation of amino acid and protein metabolism during fasting. Yale J. Biol. Med. 1950, 22, 341.

23. Parson, W., Crispell, K. R., and Ebbert, A., Jr. Abnormalities in $\mathrm{N}^{15}$ excretion rates after ingestion of tagged glycine in Cushing's syndrome and following ACTH administration. J. clin. Invest. 1952, 31, 548 .

24. Silber, R. H., and Porter, C. C. Nitrogen balance, liver protein repletion and body composition of cortisone treated rats. Endocrinology 1953, 52, 518.
25. Clark, I. The effect of cortisone upon protein synthesis. J. biol. Chem. 1953, 200, 69.

26. Shemin, D., and Rittenberg, D. Some interrelationships in general nitrogen metabolism. J. biol. Chem. 1944, 153, 401.

27. Sprinson, D. B., and Rittenberg, D. The rate of interaction of the amino acids of the diet with the tissue proteins. J. biol. Chem. 1949, 180, 715.

28. Lieberman, S., and Vande Wiele, R. Dehydroisoandrosterone, its origin and importance as a precursor of urinary 17-ketosteroids in Biochemistry of Steroids. Proceedings of the Fourth International Congress of Biochemistry. New York, Pergamon Press, 1959, vol. 4, p. 153. 